\title{
CZYM JEST OBŁAWA AUGUSTOWSKA I CZY JEST OBŁAWĄ AUGUSTOWSKĄ?
}

\begin{abstract}
Miotła Stalina. Polska północno-wschodnia i jej pogranicze $w$ czasie Obławy Augustowskiej w 1945 roku, pod redakcja Łukasza Ad a mskiego, Grzegorza Hryciuka, Grzegorza Motyki, Centrum Polsko-Rosyjskiego Dialogu i Porozumienia, Warszawa 2019, ss. 336.
\end{abstract}

W styczniu 1944 roku wojska sowieckie przekroczyły dawna granicę Drugiej Rzeczypospolitej i „wyzwoliły” Kresy Wschodnie, czyli wschodnie województwa tamtej Polski. Latem 1944 roku dotarly do wschodnich ziem obecnej Polski. W sierpniu i wrześniu 1944 roku przyglądały się zza prawobrzeżnego brzegu Wisły rzezi Warszawy.

Zimowa ofensywa sowiecka, od Bałtyku po Dunaj, ruszyła 12 stycznia 1945 roku. Wzięło w niej udział siedem frontów: 1., 2. i 3. Front Białoruski oraz 1., 2., 3. i 4. Front Ukraiński. Liczebność wojsk sowieckich wynosiła ogółem 5,7 mln żołnierzy, dysponujących 62 tys. dział, moździerzy i wyrzutni, ponad 10 tys. czołgów i dział pancernych oraz 8200 samolotów.

17 stycznia „wyzwolono” Warszawę, $z$ końcem stycznia sowieckie wojska wyszły na linię Odry, zajmując obszar między dolną Wisła a Odra. Berlin zdobyto 2 maja 1945 roku. Za kilka dni nastapiła bezwarunkowa kapitulacja III Rzeszy.

Niezależnie od operacji wojskowych, tam gdzie pojawili się Sowieci, obok ogromnej fali gwałtów na kobietach, rabunków i bezmyślnej dewastacji, zmieniał się świat w wymiarze politycznym. Rozpoczęła się intensywna sowietyzacja podbitych ziem ${ }^{1}$.

1 Informacje encyklopedyczne; N.W. Pietrow, Po scenariju Stalina: Rol'organow NKWD-MGB SSSR $w$ sowietizacii stran Central'noj $i$ Wostocznoj Jewropy 1945-1953, Moskwa 2011, passim; A. Applebaum, Za żelazna kurtyna. Ujarzmienie Europy Wschodniej 1944-1956, Warszawa 2013, passim. 
Jej najbardziej spektakularnym przykładem były liczne obławy, których celem stało się oczyszczenie zagrabionych ziem - nie tylko polskich, ale także republik bałtyckich inkorporowanych w 1940 roku - od „elementu antysowieckiego” (czyli wszystkich osobników, którzy byli podejrzewani o brak miłości do ZSRS wedle ocen własnych samych Sowietów),od niedobitków konspiracji i partyzantki niepodległościowej i jej sympatyków bądź osób ją wspierających, czy też osób objętych najbardziej „rozciagliwą” kategoria prawa sowieckiego - tzw. SOE (ros. socyalno-opasnyj elemient - społecznie niebezpieczny element). Ta ostatnia kategoria „prawna” pozwalała wyeliminować praktycznie każdego ze społeczeństwa pod niekiedy skrajnie absurdalnymi zarzutami (zob. więcej w przypisie) ${ }^{2}$.

Jeden $z$ biografów Stalina, Oleg Khlevniuk, formułuje w swojej książce przewrotna tezę, iż osobowość Stalina kształtowało m.in. także i środowisko przyrodnicze. Wokół ulubionej i najważniejszej daczy dyktatora - w Kuncewie, zwanej też „bliska dacza” (ros. bliżniaja dacza), był ogromny park o powierzchni 50 akrów $^{3}$. Posiadłość miała własna winnicę, szklarnię na cytrusy, staw z rybami, mała pasiekę. Były tam konie, krowy, kury, kaczki. Takie niby minipaństwo, któremu dyktator poświęcał dużo czasu i serca (?). Stalin osobiście nadzorował wszystkie prowadzone prace i sadzone uprawy. Zachowały się jego liczne pisemne dyrektywy kierowane do personelu pomocniczego, co, jak i kiedy robić:

a) 10 maja [1950 r.] rozpocząć sadzenie arbuzów i melonów na podniesionych grządkach; b) W połowie lipca przyciąć pnącza arbuzów i melonów [...]. Zasadzić jodły wzdłuż ścieżki od kuchni do stawu [...]. Zasiać kukurydzę w półmetrowych odstępach obok budynku głównego i pomiędzy jabłoniami obok stawu, w kierunku altany. Zasiać tam również fasolę [...]. Zasiać bakłażany, kukurydzę i pomidory wzdłuż skraju ogrodu ${ }^{4}$.

Jednym słowem widać prawdziwego gospodarza i ten pseudonim pisany dużą literą G pojawił się w końcowej części życia Stalina. Bo był Gospodarzem ZSRS, ku udręce jego obywateli i całego ówczesnego świata.

\footnotetext{
2 I tak ze znanej mi dokumentacji z Archiwum KGB w Grodnie dowiedziałem się, że „społecznie niebezpiecznym elementem” byli np. konduktor, hydraulik w uzdrowisku Druskienniki, ślusarz w zakładach kolejowych w Łapach, fryzjer w Białymstoku; nie brakuje w tej grupie tkaczy, murarzy, robotników tartacznych, właścicieli ziemskich, syna rabina, a nawet pacjenta szpitala psychiatrycznego w Choroszczy koło Białegostoku, choć ten może mógł być niebezpieczny z medycznego punktu widzenia. Zob. szerzej K. Jasiewicz, Obywatele polscy aresztowani na terytorium tzw. Zachodniej Białorusi $w$ latach 1939-1941 w świetle dokumentacji NKWD/KGB, „Kwartalnik Historyczny” 1994, nr 1, passim.

$1 \mathrm{akr}$, miara anglosaska $=4046,9 \mathrm{~m} \mathrm{kw}$.

4 O. Khlevniuk, Stalin. Nowa biografia, Kraków 2016, s. 22.
} 
Ten jego psychopatyczny, „agrarystyczny” modus operandi, jak się wydaje, przełożył się na świat ludzki, który należało oczyszczać z coraz to nowych chwastów, roślinki przycinać, przesadzać itp., co jako żywo stanowiło analogię ludobójstwa: deportacje, zsyłki, łagry, „pierekowka dusz" i ogłupiajacca propaganda to zapewne odpowiednik przycinania pnączy, gałęzi, plewienia i innych zabiegów „agrotechnicznych”. To jest klucz do zrozumienia okrutnych form sprawowania rządów, Wielkiego Terroru i wielu pomniejszych zbrodni.

Według bardzo miarodajnych i znakomicie udokumentowanych badań Grzegorza Motyki Sowieci przeprowadzili w latach 1944-1945 (także w mniejszym zakresie w latach późniejszych) na Kresach Wschodnich, choć lepiej i trafniej byłoby powiedzieć w województwach wschodnich Polski lub po prostu w Polsce ${ }^{5}$ wielką liczbę operacji zmierzajacych do wyplenienia polskich "chwastów”. We wrześniu 1944 roku Sowieci zorganizowali wielkie obławy w rejonie Lidy, Naliboków i Wilejki. Według ich dokumentacji zabili 89 osób, złapali 419 partyzantów i zatrzymali 20774 osoby, wśród których wykryto 682 „bandytów”, 306 współpracowników podziemia, 9666 uchylajacych się od służby wojskowej, kolejne 50 osób zabito ponoć w trakcie ucieczki ${ }^{6}$. Spróbujmy policzyć hipotetyczne Ofiary z ustaleń Motyki. Zabici według dokumentów to $z$ pewnością 139 osób [89+50=139]. Prawie na pewno zabito tzw. bandytów [682 osoby], podobnie „partyzantów” (wszak to synonim „bandytów”) [to 419 osób]. Zapewne nie oszczędzono współpracowników podziemia [306 osoby] i chyba rozprawiono się $z$ uchylającymi się od służby wojskowej (wszak to dezerterzy, których w czasie wojny się zabija; może czasami zsyła do karnych kompanii, co na jedno wychodzi, więc wniosek nasuwa się tylko jeden - to kolejny kontyngent do zabicia, liczacy 9666 osób). Razem: 139+682+419+306+9666=11 212 ofiar lub przy braku chęci do ułaskawień suma ta może osiagnąć niebotyczny wymiar 21282 $[89+419+20774=21$ 282]. Wydarzenia te nazwałem Obławą Nowo-

\footnotetext{
Wszak w latach 1944-1945, ale i późniejszych, nawet czasami po współczesność, Polak mieszkający w Warszawie, Krakowie, Płocku, Łomży czy Sosnowcu uważał/uważa ziemie zagrabione przez Sowietów za polskie, czyli część Polski. Kresy Wschodnie były dla pokolenia międzywojnia obszarem na wschód od granicy polsko-sowieckiej ustanowionej w 1921 roku i sięgały do dawnej granicy wschodniej Rzeczpospolitej Obojga Narodów. Wileńszczyzna, Nowogródczyzna, Polesie, Lwowskie i dalsza część Małopolski Wschodniej były jednoznacznie postrzegane nie jako jakieś Kresy Wschodnie, lecz po prostu Polska. Współcześnie pod pojęciem Kresy Wschodnie należy rozumieć nie tylko wschodnie województwa II RP, ale cały obszar okupacji sowieckiej z lat 1939-1941, co powoduje, że Rajgród, Grajewo, czy Ostrów Mazowiecka - dla nas historyków - to też część Kresów Wschodnich.

6 G. Motyka, Na białych Polaków obława. Wojska NKWD $w$ walce $z$ polskim podziemiem 1944-1953, Kraków 2014, s. 155.
} 
gródzką i termin ten wprowadziłem do obiegu naukowego, nie używajac tej nazwy cała operacje opisał Grzegorz Motyka?

Jeszcze przyjrzyjmy się danym $z$ innego, już rosyjskiego wydawnictwa, ale powiązanego ze służbami specjalnymi. I tak według stanu na 14 października 1944 roku w zachodnich obwodach BSSR w zwiazku z przeprowadzonymi operacjami likwidacji „białopolskich band” zabito 444 osoby, wzięto żywcem 927 bandytów i 9670 dezerterów z Amii Czerwonej ${ }^{8}$.

Można przyjać, że w tych liczbach raczej nie musi mieścić się Obława Nowogródzka, była ona we wrześniu 1944 roku i przy ogromnej liczbie zatrzymanych wymagało sporo czasu, aby wszystkich dokładnie przefiltrować, zwłaszcza że filtracja zapewne posiadała drugie ważne dno. Pierwszym był sprawdzenie, kto jest kim, a drugie - wydobycie informacji o innych „bandytach” i „podejrzanych”. Zreszta powyższe kategorie, kwalifikowane prawie na pewno do likwidacji, i liczby je określające daja bardzo pokaźna sumę 11041 [=444+927+9670]. A gdyby spróbować Obławę Nowogródzką z maksymalnymi wartościami zsumować $z$ wynikami powyższej „pracy”, to pojawia się imponująca liczba 32323 Ofiar [=11 041+21 282]. W roku 1945 Sowieci przeprowadzili na Kresach Wschodnich łącznie 2609 operacji czekistowsko-wojskowych, z czego 13 dużych, obejmujacych dwa-trzy obwody ${ }^{9}$.

Nie mamy nawet pojęcia, ile tysięcy nieznanych nam $z$ imienia i nazwiska osób, byłych obywateli II RP leży gdzieś zakopanych, a upływ czasu i naturalne wymarcie ich rodzin skazuja Ofiary na wieczne zapomnienie. Jak na tym tle wygląda zbrodnia zwana Obława Augustowska? Jest, niestety, jedna z 2609 operacji czekistowsko-wojskowych, jej zasięg - o czym dalej - nie kwalifikuje jej do 13 dużych, bo te obejmowały dwa-trzy obwody, czyli mniej więcej dwa-trzy województwa (obwód jest mniejszy od przedwojennego polskiego województwa).

Nie można zgodzić się $z$ interpretacją zaprezentowana przez Tadeusza Radziwonowicza i Barbarę Bojaryn-Kazberuk (choć to przed 2019 rokiem niewątpliwie najlepsza książka o Obławie Augustowskiej na polskim rynku), że:

\footnotetext{
7 K. Jasiewicz, Obława Augustowska - stan badań, ich uwarunkowania i perspektywy, „Studia z Dziejów Rosji” 2018, z. 2; wersja internetowa. Zob. też idem, Siedemdziesiata rocznica Obławy Augustowskiej: w poszukiwaniu genezy ostatniej zbrodni sowieckiej na obywatelach polskich w lipcu 1945 roku, w: Whołdzie ofiarom obławy augustowskiej z lipca 1945 roku, red. St. Wysocki, Suwałki 2015.

8 Organy gosudarstwiennoj biezopasnosti $w$ Wielikoj Otieczestwiennoj Wojnie, t. 5 , cz. 2: Granicy SSSR wosstanowlieny, 1 ijula-31 diekabrja 1944 goda, Moskwa 2007, s. 458.

9 G. Motyka, Na białych Polaków obława..., s. 163.
} 
Planując operację, dowództwa sowieckie w swych szacunkach objęły zapewne cały obszar lasów augustowskich i okolice, łącznie $z$ ich częścią na Litwie i Białorusi. Nie ulega też wątpliwości, że za swój cel uznały likwidację podziemia niepodległościowego (polskiego i litewskiego) do tego stopnia, by zapobiec jego odrodzeniu. Po to zmierzały unieszkodliwić, zabić, czy aresztować jak najwięcej partyzantów i konspiratorów oraz udzielających im różnorakiego wsparcia współpracowników, a także zneutralizować ich społeczna bazę. Dlatego należało na dużym przecież obszarze, który $z$ racji warunków naturalnych sprzyjał działaniom partyzanckim i konspiracji, w krótkim czasie dotrzeć do wielu miejsc, w tym trudno dostępnych, zatrzymać, sprawdzić i przesłuchać nie setki, a tysiące osób, nie wykluczając członków rodzin, znajomych i sąsiadów „bandytów i ich popleczników”10.

Nie można zgodzić się $z$ taka hipoteza, przecza jej bowiem liczne dokumenty zamieszczone w Miotle Stalina, gdzie wręcz z zegarmistrzowska precyzja określa się ruch w terenie poszczególnych pododdziałów Armii Czerwonej ${ }^{11}$.

Dla przykładu przyjrzyjmy się 69. Korpusowi Strzeleckiemu:

Do wyjścia jednostek 69. KS na wskazaną rubież na południowym brzegu Kan.[ału] Augustowski od śl.[uzy] Swoboda do Czarny Bród zamknąć siłami wydzielonymi $z$ dywizji drugiego eszelonu. Linia rozgraniczenia $z$ lewej: jez. Netta, jez. Białe, jez. Studzieniczne, Kan. Augustowski, jez. Mikaszewo, dalej wzdłuż rz. Czarna Hańcza do Wołkuszek. Sztab Korpusu o 10.00, 11.7.1945 r. - Augustów ${ }^{12}$.

Nawet na podstawie szyfrogramu Wiktora Abakumowa rzuca się w oczy iście „sowiecki porządek”: Litwinów przekazuje się właściwym terytorialnie organom NKWD-NKGB Litewskiej SSR, choć prościej byłoby tego nie robic ${ }^{13}$.

Warto przypomnieć obarczone tym samym błędem, połaczonym z dużą doza pychy, ustalenia samozwańczego Obywatelskiego Komitetu i Alicji Maciejowskiej, które badania nad Obława skierowały na boczny tor i nie zasługuja na poważne traktowanie. Powstały 2 sierpnia 1987 roku w Suwałkach ów Komitet (pełna nazwa Obywatelski Komitet Poszukiwań Mieszkańców Suwalszczyzny Zaginionych w Lipcu 1945 r.) rościł sobie prawo do wiedzy niemal absolutnej, co publicznie wyraziła warszawska dziennikarka, Alicja Maciejowska, członkini

10 T. Radziwonowicz, B. Bojaryn-Kazberuk, Obława augustowska 1945. Okoliczności i ofiary $w$ dokumentach archiwalnych, Suwałki 2017, s. 47.

${ }_{11}$ Miotła Stalina. Polska północno-wschodnia $i$ jej pogranicze $w$ czasie Obławy Augustowskiej w 1945 roku, red. Ł. Adamski, G. Hryciuk, G. Motyka, Warszawa 2019, passim.

12 Rozkaz bojowy nr 005/OP, Sztab Armii 50., w: Miotła Stalina..., s. 15.

13 Szyfrogram nr 25212 W. Abakumowa, szefa GUKR SMIERSZ do narkoma Ł. Berii z 21 lipca 1945 r., w: N. Pietrow, Psy Stalina, Warszawa 2012, s. 225. 
tegoż Komitetu 14 października 2011 roku w Domu Spotkań z Historia $\mathrm{w}$ Warszawie. Prowadziłem tam spotkanie $z$ dr. Nikita Pietrowem, wiceprzewodniczącym Stowarzyszenia „Memoriał” w Moskwie, prezentując jego ogromny dorobek w zakresie badań nad sowieckim aparatem bezpieczeństwa i jego zbrodniami, w tym Obława Augustowska. Na sali była Maciejowska w towarzystwie kilku osób, byłych członków owego Obywatelskiego Komitetu. Stwierdziła, że wszelkie spekulacje na temat liczby Ofiar Obławy sa nie uprawnione, gdyż oni sprawę „zbadali” gruntownie, sporządzili listę zaginionych. Spenetrowali cały teren objęty Obława, ustalili, że odbywała się ona tylko po polskiej stronie i że w tej sprawie dyskusja jest bezprzedmiotowa.

Kilka lat później w wydawnictwie IPN „Pamięć.pl”, wydawanym przez Białostocki Oddział IPN, pojawiła się informacja, że jedna $z$ bardzo aktywnie uczestniczących w pracach Komitetu osób, Paweł Mikłasz, szef podziemnego wydawnictwa „Myśl” w Warszawie, który finansował prace przy zbieraniu relacji $\mathrm{w}$ terenie, okazał się tajnym współpracownikiem SB. W „badaniach” pomagali jego czterej pracownicy zatrudnieni w wydawnictwie „Myśl”14. Naiwne wydaje się tłumaczenie tego faktu przez autorkę owego tekstu lustrującego, Annę Pyżewska, z Oddziału Białostockiego IPN, że:

[...] mimo jego podwójnej roli żaden członek komitetu [tak w oryginale; winno być $z$ dużej litery] nigdy nie został aresztowany, nie skonfiskowano też zebranych materiałów ${ }^{15}$.

Można ten fakt zinterpretować zupełnie inaczej. Wszak to jedna $z$ najbardziej znanych technik stosowanych w służbach specjalnych, zwłaszcza popularna $\mathrm{w}$ sowieckich oraz $\mathrm{w}$ szkolonych przez ich doradców służbach tzw. państw socjalistycznych. Polega na stworzeniu organizacji/instytucji etc. pod własna kontrola jedynie w celu przyciagnięcia najaktywniejszych w danej sprawie elementów przy jednoczesnym uważnym przyglądaniu się celom i działalności śledzonej grupy.

Maciejowska wraz $z$ członkami Obywatelskiego Komitetu odwiedzili sto kilkadziesiąt miejscowości, przeprowadzili kilkaset rozmów i zebrali dane o 370 zaginionych osobach. Należy dodać, że korzystali także obficie $z$ dorobku kilku rad narodowych, które sporządzały zaraz po Obławie swoje listy zaginionych, czym się specjalnie nie pochwalili. Komitet zakończył działalność przekazaniem zebranego materiału do

14 A. Pyżewska, Komitet niosacy nadzieję, „Pamięć pl” (dodatek bezpłatny do miesięcznika „Pamięć pl.” pt. Obława Augustowska), Warszawa, bdw. [lipiec 2015], s. 25.

15 Ibidem. 
Prokuratury Wojewódzkiej w Suwałkach na początku 1992 roku, a ta 27 lutego wszczęła śledztwo, zawieszone $z$ braku postępów 5 listopada 1992 roku. Później akta trafiły do Archiwum IPN w Białymstoku ${ }^{16}$.

Zupełnie nowym dokumentem, który także obalił - jeszcze przed premiera Miotly Stalina - „teorie” Maciejowskiej, jest zdobyta przez Zwiazek Pamięci Ofiar Obławy Augustowskiej ${ }^{17}$ relacja mieszkańca wsi Kadysz (Rządowy) w obwodzie grodzieńskim, leżącej przy starej drodze z Sopoćkiń do Kopciowa (Republika Litewska), na północ od Sopoćkiń, $4 \mathrm{~km}$ od granicy nad rzeka Czarna Hańcza (do ustalenia granicy w 1946 roku wieś leżała w woj. białostockim, w pow. augustowskim, gmina Wołłowiczowce $)^{18}$, $z$ owej relacji wynika, że i tam była przeprowadzona wielka operacja przeczesywania lasów i domostw ${ }^{19}$. „Szli tyraliera. Po lesie wszędzie przeszukiwali, po domach [...]. Sowietów było jak meszek, pełno"20. Kategoryczne stwierdzenia Maciejowskiej wygłoszone w Domu Spotkań z Historia w Warszawie ${ }^{21}$, iż po drugiej stronie granicy (współczesnej) polsko-białoruskiej żadnej obławy nie było - w świetle publikowanych dokumentów w recenzowanej książce i świadectwa $z$ Kadyszu - nawet nie można uznać za żart, raczej za publiczne przyznanie się do niewiedzy i wyjątkowej arogancji ${ }^{22} . Z$ opublikowanego dokumentu w książce Grzegorza Motyki i innych wynika jasno, że pod pojęciem Obława Augustowska należy rozumieć przeczesanie lasów w powiatach augustowskim i suwalskim przez Armię Czerwona, bez udziału Wojsk Wewnętrznych NKWD, w ogóle w żadnym momencie - nie tylko Obławy Augustowskiej, ale w ogóle obław na Kresach Wschodnich - nie pojawia się osławiona 62 Dywizja WW $\mathrm{NKWD}^{23}$.

${ }^{16}$ K. Jasiewicz, Obława Augustowska - stan badań, ich uwarunkowania i perspektywy, „Studia z Dziejów Rosji i Europy Środkowo-Wschodniej” 2018, z. 2, wersja internetowa, passim.

${ }_{17}$ Związek Pamięci Ofiar Obławy Augustowskiej powstał 15 marca 2009 r., rejestracja w KRS miała miejsce 17 lipca 2009 r.; nr KRS 0000333459. Zrzesza prawie wszystkie rodziny Ofiar; przewodniczacy - ks. prałat Stanisław Wysocki.

18 https:/pl.wikipedia.org./wiki/Kadysz_(rejon_grodzieński).

19 Relacja anonimowa $z$ przebiegu Obławy Augustowskiej (?) we wsi Kadysz na Grodzieńszczyźnie. Nagrywający świadka był nieprzygotowany do zbierania informacji, nie sprawdził sprzętu i duża część relacji nie została nagrana lub nagrana niewyraźnie. Rozmowa była chaotyczna, świadek nie był właściwie indagowany; ze względu na bezpieczeństwo świadka i osoby nagrywającej nie podaję ich nazwisk.

${ }^{20}$ Relacja anonimowa $z$ przebiegu Obławy Augustowskiej (?) we wsi Kadysz na Grodzieńszczyźnie.

${ }^{21}$ Zachował się zapis fonograficzny $\mathrm{z}$ tego spotkania.

22 Informacja $z$ autopsji.

${ }^{23}$ Miotła Stalina..., passim. W szczególności zob. rozkaz bojowy nr 005/OP Sztab Armii 50. z 11.7.1945 r. 
Również termin przeprowadzenia Obławy Augustowskiej jest krótszy, niż to wynika $z$ dotychczasowej wiedzy (od 12 do 18 lipca 1945 roku $^{24}$ :

1. Według danych agenturalnych w lasach augustowskich i pobliskich terenach operuja bandy „Armii Krajowej” o ogólnej liczebności do 8000 ludzi. [Rozkaz bojowy $\mathrm{nr}$ 005/OP z 11 lipca 1945 roku, Sztab Armii 50.25]. Bandy napadaja na żołnierzy Armii Czerwonej i przedstawicieli lokalnych organów polskiej władzy. Bandyci ci zorganizowani są na wzór wojskowy, mają scentralizowane kierownictwo, system zarzadzania, punkty oporu i tajne składy broni.

2. Wojska 50. Armii w okresie od 12.7.1945 do 18.7.1945 prowadza operacje przeczesywania masywu leśnego i miejscowości w rejonie: Suwałki, Augustów, Jaziewo, Lipsk, Druskienniki, Sejny.

Poczatek operacji $-8,00,12.7 .1945$ r. $[\ldots]^{26}$.

Stwierdzenie w najbardziej znanym dokumencie dotyczacym Obławy Augustowskiej - chodzi o szyfrogram z 21 lipca 1945 roku zawierajacy propozycję wymordowania pojmanych, zidentyfikowanych „bandytów”, zaangażowanie generałów Zielenina i Gorgonowa oraz specjalnego batalionu SMIERSZ, afiliowanego przy 3. Froncie Białoruskim, nie było przypadkowe. Przeczytajmy fragmenty tego szyfrogramu nr 25212 z 21 lipca 1945 roku Wiktora Abakumowa, szefa GUKR (Zarząd Główny Kontrwywiadu przy Ludowym Komisariacie Obrony ZSRS) SMIERSZ (Smiert' Szpionam=Śmierć Szpiegom) do narkoma spraw wewnętrznych Ławrientija Berii, które dają bardzo dużo do myślenia i zostana poddane analizie. Drukiem rozstrzelonym zaznaczam sformułowania ważne dla zrozumienia metod działania Sowietów.

Fragment pierwszy: „W tym celu [mowa o likwidacji osób rozpoznanych jako „bandyci”, czyli członkowie AK] zostanie wydzielona grupa operacyjna i batalion wojsk Zarzadu SMIERSZ 3. Frontu Białoruskiego, sprawdzone w praktyce podczas szeregu akcji kontrwywiadowczych [...]".

Fragment drugi: „Pozostałe 828 osób sprawdzimy w ciagu pięciu dni $[\ldots]^{\prime 27}$.

${ }^{24}$ Inskrypcja na Grobie Nieznanego Żołnierza podaje błędnie daty Obławy Augustowskiej na 12-19 lipca $1945 \mathrm{r}$.

25 50. Armia została sformowana 16 VIII 1941 roku na bazie 2. Korpusu Strzeleckiego w składzie Frontu Briańskiego. Latem 1944 roku w składzie 1. Frontu Białoruskiego uczestniczyła w operacji białoruskiej, zajmujac m.in. Nowogródek, Skidel i Grodno. Pod koniec sierpnia 1944 roku dotarła do linii Biebrza-Narew w rejonie Goniądza i Osowca. W 1945 roku 50. Armia uczestniczyła w operacji wschodniopruskiej - najpierw w składzie 2., a od 11 II 1945 roku 3. Frontu Białoruskiego. W dniach 6-9 IV 1945 roku oddziały 50. Armii brały udział w szturmie Królewca. Miotła Stalina..., przypis 1, s. 53.

${ }_{26}$ Rozkaz bojowy nr 005/OP z 11.7.1945 r., w: Miotła Stalina..., s. 53 nn.

27 Szyfrogram nr $25212 \mathrm{~W}$. Abakumowa, szefa GUKR SMIERSZ do narkoma Ł. Berii z 21 lipca 1945 r., w: N. Pietrow, Psy Stalina, s. 225. 
Zaznaczone wyrazy fragmentu pierwszego w sposób niezbity dowodza, że batalion wojsk Zarządu SMIERSZ 3. Frontu Białoruskiego wielokrotnie uczestniczył w licznych akcjach ludobójczych, tu zwanych „kontrwywiadowczymi”, teoretycznie pewnie brał udział w około połowie $z$ tych $2609^{28}$, czyli w około 1300 operacjach likwidacji polskich „chwastów” tylko w 1945 roku (na terenie tzw. Zachodniej Ukrainy zapewne robiła to inna grupa moskiewska $z$ pomoca jakiegoś innego batalionu SMIERSZ będącego w dyspozycji jednego $z$ czterech frontów ukraińskich. A najpewniej każdy Front posiadał swój SMIERSZ, a ten swój batalion).

Wiemy z ustaleń Motyki, że operacje oczyszczania lasów i miejscowości w dużym zakresie były już przeprowadzane w 1944 roku (np. wspomniana Obława Nowogródzka). Działo się to na terytorium tzw. Zachodniej Białorusi w jurysdykcji SMIERSZ 3. Frontu Białoruskiego i jego batalionu specjalnego, który w praktyce dość wcześnie, niejako $z$ marszu, zdobywał „cenne” doświadczenia ${ }^{29}$.

$Z$ kolei owe „pięć dni” we fragmencie drugim świadczy o wielkim „kunszcie” i doświadczeniu funkcjonariuszy SMIERSZ. Zapewne wypraktykowali, że jedni załamują się po jednym dniu, inni po dwóch, trzech dniach ustawicznego bicia i innych tortur, a pewnie każdy poddawał się najpóźniej piątego dnia. Stąd nie ma w dokumencie określenia „około” lub np. „ośmiu dni”30. Istniała też, co wiemy ze znanych dokumentów ${ }^{31}$, kooperacja między frontowymi strukturami a terenowym aparatem NKWD-NKGB. Mówi o tym ten sam dokument - szyfrogram Abakumowa o przekazywaniu pojmanych w obławie Litwinów litewskim organom NKWD-NKGB wedle właściwości terytorialnej ${ }^{32}$.

Sięgnijmy ponownie do anonimowej relacji $z$ Kadysza. Relacjonista podaje, że aresztowano wszystkich mężczyzn ze wsi. Zostali przewiezieni na Litwę i tam przebywali około tygodnia. Prawie wszystkich wypuścili. „Strach było pytać gdzie ich przetrzymywali”. Nie jest jasne - „przepadli bez wieści ci, co ukrywali się po lasach”? W relacji zostały podane nazwiska mężczyzn przed trzydziestką $z$ tejże wsi (Jan Lakiewicz, Władysław Promski, Bolesław Lis), którzy zaginęli bez wieści.

28 G. Motyka, Na białych Polaków obława..., s. 163.

29 Ibidem, s. 163.

30 Zob. ponownie szyfrogram nr 25212 W. Abakumowa, szefa GUKR SMIERSZ do narkoma Ł. Berii z 21 lipca 1945 r., w: N. Pietrow, Psy Stalina, s. 224-225.

31 Ibidem.

32 Ibidem. Może tu też dochodzić do pewnego przeinaczenia tych danych, czy w dokumencie chodzi o osoby narodowości litewskiej (wtedy Litwini), czy też o osoby zamieszkałe na stałe/tamże zameldowane, wtedy moga to też być Polacy z AK, którzy próbują uciec z gęstwiny obław do centrum Polski, licząc, że tam uda im się przetrwać w lepszych warunkach. 
Ich rodziny zostały wywiezione ${ }^{33}$. To analogia ze Zbrodnią Katyńska tam też wywieziono rodziny zamordowanych w deportacji 13 kwietnia 1940 roku. Taka była praktyka i tradycja systemu bolszewickiego. Tak postępował Gospodarz, „wielki ogrodnik”.

Tępienie „chwastów”, wprawdzie już pojedynczych, trwało dość długo. W Puszczy Augustowskiej jakieś nieliczne grupki czy pojedyncze osoby kryły się po ostępach leśnych jeszcze w latach pięćdziesiatych $^{34}$. Nieźle rozwinięte partyzantki utrzymywały się do lat pięćdziesiątych w państwach bałtyckich (Litwa, Łotwa, Estonia), znacznie słabsze było podziemie białoruskie, choć też dotrwało do początków lat pięćdziesiątych. Polskie podziemie na Kresach Wschodnich istniało w szczątkowej postaci do około 1948 roku $^{35}$. A ostatniego partyzanta UPA Sowieci pochwycili w 1960 roku $^{36}$.

Wraz z Armią Czerwona na ziemiach polskich pojawiło się tak zwane Ludowe Wojsko Polskie oraz marionetkowe władze powołane w Moskwie i przez Moskwę - Polski Komitet Wyzwolenia Narodowego. PKWN oficjalnie powstał 21 lipca 1944 roku, a o swoim istnieniu powiadomił 22 lipca 1944 w Chełmie Lubelskim, ogłaszając Manifest Lipcowy ${ }^{37}$. Aczkolwiek nie jest zaskoczeniem, iż w Obławie Augustowskiej wzięli udział funkcjonariusze UB, a także - jak się dotychczas przyjmowało - jedna kompania wydzielona $z$ 1. Praskiego Pułku Piechoty, dodajmy, że była to kompania fizylierów (a więc dobrze wyposażona w broń maszynowa) pod dowództwem por. Maksymiliana Sznepfa, to pojawia się uzasadnione pytanie, czy brała ona udział tylko w Obławie Augustowskiej, czy nieco innej operacji przeciwpartyzanckiej. Poszukiwała ona bowiem „bandytów” od 23 lipca do 8 sierpnia 1945 roku w okolicach Siemiatycz i tamże pochwyciła 67 owych „bandytów”, w sierpniu działała w okolicach Knyszyna, a wcześniej przeczesała Drohiczyn i okoliczne wsie ${ }^{38}$. A to - jak się wydaje - były obszary dość odległe od Suwalszczyzny i Ziemi Augustowskiej, co prowadziło do spekulacji (tu także dodam i z moim udziałem) jakoby Obława Augustowska była ogromną obławą obejmująca całą Polskę Północno-Wschodnią, południową Litwę, Grodzieńszczyznę i pas ziemi wzdłuż powojennej gra-

${ }^{33}$ Relacja anonimowa $z$ przebiegu Obławy Augustowskiej (?) we wsi Kadysz na Grodzieńszczyźnie.

${ }^{34}$ Relacja ks. prałata Stanisława Wysockiego.

35 G. Motyka, R. Wnuk, T. Stryjek, A.F. Baran, Wojna po wojnie. Antysowieckie podziemie $w$ Europie Środkowo-Wschodniej w latach 1944-1953, Gdańsk-Warszawa 2012, passim.

${ }^{36}$ G. Motyka, Ukraińska partyzantka 1942-1960, Warszawa 2006, passim.

37 Informacje encyklopedyczne.

38 CAW, sygn.III.2-234 bp. 
nicy polsko-sowieckiej, gdzieś daleko na południe, może nawet poza Białystok $^{39}$. Dopiero studia nad dokumentami właśnie opublikowanymi w Miotle Stalina uprawniają do jednoznacznego stwierdzenia, że Obława Augustowska i - jak się okazuje - liczne inne akcje przeciwpartyzanckie, które miały miejsce w całym pasie przygranicznym od Suwalszczyzny i Ziemi Sejneńskiej na północy po Podkarpacie odbyły się $z$ bardzo licznym udziałem wojsk LWP i były to całkowicie odrębne operacje. Wedle ściśle tajnego rozkazu nr 00289/Op. z 24 maja 1945 roku, podpisanego przez p.o. szefa Sztabu Głównego WP, gen. bryg. Jana Jośkiewicza i naczelnego dowódcę WP, marszałka Michała Rolę-Żymierskiego podjęto zakrojone na szeroką skalę działania zbrojne wymierzone $\mathrm{w}$ polskie podziemie niepodległościowe $\mathrm{w}$ całym szerokim pasie przylegającym do współczesnej granicy $z$ Białorusia i Ukraina, poczynając od powiatu Białystok, i dalej na południe przez powiaty: Hajnówka, Białowieża, Łuków, Biała Podlaska, Parczew, Kock, Lubartów, Dęblin, Hrubieszów, Chełm, Krasnystaw, Biłgoraj, Janów, Lubaczów, Sieniawa i Jarosław. Do realizacji tego celu skierowano trzy dywizje: 1. Dywizję Piechoty (DP) rozlokowano w Siedlcach, 3. DP w Lublinie, 9. DP w Rzeszowie. Określono też precyzyjnie zakres terytorialny operowania poszczególnych związków taktycznych. I tak 1. DP będzie prowadzić działania przeciwpartyzanckie w woj. białostockim, wschodnich powiatach woj. warszawskiego i w powiatach Siedlce, Łuków i Biała Podlaska w woj. lubelskim; 3. DP w woj. lubelskim, 9. DP będzie wykorzystana w woj. rzeszowskim ${ }^{40}$.

To jest właśnie mord założycielski Polski Lubelskiej, późniejszego PRL. W globalnym wymiarze bowiem LWP licznie uczestniczy w tępieniu Polaków mających inną wizję ładu powojennego, których powszechnie nazywa się „bandytami”.

Rozkazuję formacjom wydzielonym do tego celu zlikwidować w zdecydowany i energiczny sposób w jak najkrótszym czasie bandy dywersyjne i zapewnić miejscowym władzom i ludności normalne warunki pracy ${ }^{41}$.

Dużą aktywność wykazał także resort Bezpieczeństwa Publicznego. I tak ze ściśle tajnego „Okólnika nr 9 o przeprowadzeniu akcji likwidacji band” z 12 czerwca 1945 roku podpisanego przez Stanisława Radkiewicza, ministra bezpieczeństwa publicznego, dowiadujemy się wielu interesujących szczegółów.

39 K. Jasiewicz, Obława Augustowska - stan badań..., passim.

40 Rozkaz nr 00289/Op.z 24 maja 1945 r., w: Miotła Stalina..., s. 3.

41 Rozkaz nr 00289/Op., w: Miotła Stalina..., s. 3. 
Na podstawie decyzji rządu rozpoczna się masowe akcje likwidacji grasujących band, które będą przeprowadzać jednostki wojskowe przy bezpośrednim udziale odpowiednich urzędów BP [...]. Dla ogólnego kierownictwa tą akcją została powołana Główna Komisja Polityczna dla spraw Walki z Bandytyzmem. Powołuje się również Wojewódzkie Komisje Polityczne w Białymstoku, Lublinie, Siedlcach i Rzeszowie [...]. Do dowództwa każdej dywizji będa przydzieleni jako doradcy oficerowie AL $z$ doświadczeniem partyzanckim. Na teren woj. białostockiego przydzielony jest płk Alef [Gustaw Alef-Bolkowiak], lubelskiego - płk [Grzegorz] Korczyński, rzeszowskiego - płk [Mieczysław] Moczar [właśc. Mikołaj Demko] [...]. Urząd Bezpieczeństwa powinien przygotować dokładne materiały o bandach i przekazać je dowództwu odpowiedniej jednostki wojskowej [...]. Podkreśla się, że nie powinno być ani jednej operacji bez udziału w niej organów bezpieczeństwa [...]. Bandytów, którzy dobrowolnie nie zgłaszaja się i nie składają broni, należy ścigać $z$ całą bezwzględnością [...]. Milicja Obywatelska winna przyjać szeroki udział w przeprowadzonej akcji. Komendant Główny MO wyda podwładnym sobie organom odpowiednie zarządzenie ${ }^{42}$.

Kolejne rzeczy rzucajace się w oczy w dokumentach. Mowa jest w nich o współdziałaniu $z$ Armia Czerwona stacjonująca w „pasie operacji"43, także o bezwzględnym traktowaniu dowódców i oficerów „band” oraz osób „stawiających opór z bronią w ręku”. To też jest najlepszym dowodem współdziałania w akcji ludobójstwa.

W dokumencie podpisanym przez Naczelnego Dowódcę Wojska Polskiego, marszałka Michała Żymierskiego, czytamy:

W toku akcji przeciwko bandom do niewoli nie brać [...] przywódców i oficerów dowództwa dywersyjnego, [...] dywersantów stawiajacych opór $z$ bronia w ręku [...] w toku akcji dążyć do unicestwienia bandytów i dywersantów ${ }^{44}$.

$\mathrm{Na}$ tym tle dopiero uwidacznia się specyfika Obławy Augustowskiej, gdyż w praktyce przeprowadzaja ja sami Sowieci (tylko Armia Czerwona i SMIERSZ), jedna kompania LWP i zapewne pewna liczba funkcjonariuszy UB i MO z tych powiatów oraz $z$ Białegostoku czy woj. białostockiego. Operacja sowiecka z ogromna liczba żołnierzy była starannie przygotowana i rozpisana na fazy. Przeczesywanie było dokładne. Posuwano się równa linią tyraliery, starannie penetrujac parowy, wąwozy, gęste zarośla itp., za nią szła druga tyraliera, a przed tyralierami operowały małe grupki zwiadowców pewnie ze SMIERSZ,

${ }^{42}$ Okólnik nr 9 o przeprowadzeniu akcji likwidacji band z 12 czerwca 1945 r.,w: Miotła Stalina..., s. 20-22.

${ }_{43}$ Rozkaz nr 005/Op. dowódcy 1. Dywizji Piechoty im. T. Kościuszki gen. bryg. Piotra Bewziuka i szefa sztabu 1. DP, ppłk. dypl. Piotra Poliszczuka z 13 czerwca 1945 r., w: Miotka Stalina..., s. 24-25.

${ }_{44}$ Rozkaz nr 00123 Naczelnego Dowództwa WP z 14 czerwca 1945 r., w: Miotła Stalina..., s. 26-27. 
które - sygnalizuję - odegrały zapewne ogromna rolę w powodzeniu operacji. Dlaczego Sowieci zdecydowali się na użycie tak ogromnej masy własnego wojska na relatywnie niezbyt dużym obszarze?

Były dwa powody. Pierwszy dość jasno widać w opublikowanych dokumentach. Prości polscy żołnierze $z$ ludu zdecydowanie nie mieli ochoty na walki bratobójcze i mordowanie swoich rodaków. Była im też zapewne zupełnie obca ideologia przynoszona na sowieckich bagnetach. I tak w elitarnej, historycznie pierwszej dywizji LWP 1. Dywizji Piechoty im. Tadeusza Kościuszki żołnierze i oficerowie najwyraźniej bojkotowali rozkazy przełożonych.

Górnolotny frazes $z$ rozkazu nr 0011 „O odpowiedzialności za uchylanie się od boju z dywersantami” z 30 czerwca 1945 brzmiał: „My, Kościuszkowcy, winniśmy przodować i być wzorem w wykonywaniu obecnego nowego zadania"45. W praktyce wygladało to zupełnie inaczej. Żołnierze 1. DP wyraźnie nie mieli ochoty na udział w operacji ludobójczej, co przełożyło się na ostrą reakcję dowództwa dywizji. Posypały się więc liczne kary: jednego oficera oddano pod sąd polowy, kilkudziesięciu żołnierzy, którzy odmówili strzelania do „bandytów", skierowano do karnej kompanii ${ }^{46}$. W 1. Praskim Pułku Piechoty 11 lipca 1945 roku w Białymstoku przed frontem pułku zebranym na placu alarmowym odbyła się publiczna egzekucja trzech żołnierzy, którzy odmówili walki z „bandami”, zdezerterowali i wzięli aktywny udział „w walkach przeciwko zbrojnym siłom Państwa Polskiego - Wojsku Polskiemu"47.

Powód drugi, że tzw. Obława Augustowska poniekąd przeczesuje teren zwany „przesmykiem suwalskim”, bardzo ważny ze strategicznego punktu widzenia obszar, przez który odbywa się łączność/komunikacja $z$ dawnymi niemieckimi Prusami Wschodnimi przywłaszczonymi przez Sowietów prawem kaduka. Może nawet był pomysł, by nie tylko dobrze zabezpieczyć drogi komunikacyjne nowej kolonii z macierza, ale w ogóle zajać całą Suwalszczyznę i Ziemię Augustowską i stworzyć tym samym jednolity organizm państwowy?

Trudno też, w świetle wyżej prezentowanych danych - zwłaszcza mam na myśli statystykę operacji czekistowsko-wojskowych za 1945 rok; chodzi o 2609 operacji, w tym 13 dużych obejmujących dwa-

\footnotetext{
${ }^{45}$ Rozkaz nr 0011 dowódcy 1. DP im. T. Kościuszki z 30 czerwca 1945 r., w: Miotła Stalina.... s. 30-33.

46 Ibidem.

47 Meldunek sytuacyjny sztabu 1. Praskiego Pułku Piechoty nr 0296 z 12 lipca 1945 r., w: Miotła Stalina..., s. 64.
} 
-trzy obwody ${ }^{48}$ - uznać Obławę Augustowską za ostatni mord sowiecki dokonany po zakończeniu II wojny światowej. Należałoby poznać wszystkie obławy, ich zasięg terytorialny, czas prowadzenia operacji, liczby i kategorie osób pochwyconych w ich wyniku. Policzyć Ofiary. Dopiero wtedy można sformułować sensowne hipotezy.

Właściwie też należałoby się zastanowić, jak ten ogromny akt ludobójstwa na całych Kresach Wschodnich (bo nie miejmy złudzeń co do Ofiar śmiertelnych) nazwać? - Archipelag Obław/Zbrodni Kresowych? Czy też znając/poznając dokładnie ich topografię przypisać im nazwy własne, jak np. Obława Białostocka, Obława Sokólska, Białowieska, Hrubieszowska, Chełmska, Lubaczowska, etc.? ${ }^{49}$ Czy też próbować dokonywać mniej lub bardziej udanych fuzji lingwistycznych. Jako przykład można podać operację czekistowsko-wojskowa $\mathrm{w}$ dniach 22 czerwca-16 lipca 1945 roku przeprowadzoną w rejonie oszmiańskim i ostrowieckim w obwodzie mołodeczańskim. Wedle rozpoznania do wyłapania było tam ok. 200 dezerterów, ok. 400 uchylających się od poboru i kilka grup partyzanckich o łącznej liczebności kilkudziesięciu osób $^{50}$. To niewątpliwie mała/małe obławy. I można je różnie nazwać: Obława Oszmiańska, Obława Ostrowiecka, Obława Oszmiańsko-Ostrowiecka lub zbiorczo wedle nazwy obwodu - Obława Mołodeczańska. To jest olbrzymie pole do wielkich badań, które trzeba przeprowadzić, choć stosunki polsko-rosyjskie zapewne nie będa temu sprzyjać.

Frapującym, choć może bardzo okrutnym, składnikiem prawdy o obławach o różnych nazwach moga stać się ujawnione w trakcie badań szczególne metody wydobywania informacji w bardzo krótkim czasie przez zwiadowców. Często bowiem bywało tak - jak wspomniałem - że przed główna tyraliera operowała mała grupa zwiadu, która próbowała pochwycić pojedynczych albo lepiej kilku (zaraz napiszę dlaczego) partyzantów lub osób $z$ jakichś powodów ukrywających się po lasach czy w śródleśnych wioseczkach/chutorach. Natychmiastowe wydobycie informacji - a przebieg obław wskazuje, że tak się zdarzało - gwarantowało wyłapanie wszystkich poszukiwanych. Musiały to być tortury szczególnie drastyczne i skuteczne, zajmujace mało czasu ${ }^{51}$. Spekulowaliśmy o przypalaniu genitaliów, obcinaniu palców, uszów,

48 G. Motyka, Na białych Polaków obława..., s. 163.

49 Miotła Stalina..., passim.

50 Raport z przeprowadzenia czekistowsko-wojskowej operacji likwidacji grup bandyckich, pojedynczych bandytów i in. elementu przestępczego w okresie 22 czerwca 1945 r. do 16 lipca 1945 r. w rejonach oszmiańskim i ostrowieckim [obwodu mołodeczańskiego], w: Miotła Stalina..., s. $153 \mathrm{nn}$.

51 Do takich wniosków doszliśmy wspólnie z prof. Grzegorzem Motyką podczas naszych okresowych dyskusji naukowych w kuluarach Instytutu Studiów Politycznych PAN. 
nosów, bo faktycznie po takim przesłuchaniu z pewnością Ofiara musiała być zabita, a jej ciało ukryte. Wygodniej było takie tortury zaprezentować na jednym pochwyconym, by pozostałych mocno wystraszyć i zmiękczyć, obiecując - bez pokrycia - np. pobyt w obozie filtracyjnym, nawet zesłanie. Bo byłoby to nic, w porównaniu do sceny, która musieli obejrzeć. Przypuszczam, że nasze rozumowanie było prawidłowe, bo refleksem tego może być okrutna śmierć płk. Pawła Wasiljewa i jego kompanów. Wpadli oni w zasadzkę 7 lipca 1945 roku w rejonie wsi Brzezina, położonej $30 \mathrm{~km}$ na południowy zachód od Bielska, urządzona przez oddział AK (AKO) dowodzony przez Zygmunta Błażejewicza, ps. Zygmunt. Wszystkim pojmanym Sowietom odcięto organy płciowe i wykłuto oczy, a maszynistce przypalano piersi i gardło ${ }^{52}$. Aczkolwiek wojna prowadzi do zezwierzęcenia (chociaż to określenie obraża zwierzęta), to mało prawdopodobne, by taki incydent zdarzył się bez istotnego (ale też nie do zaakceptowanego) powodu. Może ktoś odnalazł polskie zwłoki w lesie w takim właśnie stanie, bo skuteczność zwiadu polegała na błyskawicznym wykorzystaniu wydobytej torturami informacji. Czas działał na niekorzyść, a potem nie zdążono lub zapomniano zakopać zwłoki. Reszta układa się w logiczną całość.

$Z$ przykrościa muszę odnotować kilka wpadek autorów we Wstępie. $Z$ uporem powtarzaja oni niby mantrę nieprawdziwa liczbę Ofiar Obławy Augustowskiej, chociaż robią to bardzo asekuracyjnie: „Skala zbrodni - co najmniej 600 rozstrzelanych - lokuje ją wśród wydarzeń szczególnych"53. Niestety, powtarzaja tym samym niedorzeczna i nienaukowa interpretację słynnego i cytowanego w niniejszym tekście wielokrotnie szyfrogramu Abakumowa z 21 lipca 1945 roku, w którym szef SMIERSZ proponuje Berii:

Zlikwidować wszystkich zidentyfikowanych bandytów w liczbie 592 osób. W tym celu zostanie wydzielona grupa operacyjna i batalion wojsk Zarządu SMIERSZ 3. Frontu Białoruskiego, sprawdzone w praktyce podczas szeregu akcji kontrwywiadowczych. Pracownicy operacyjni i żołnierze batalionu dostana precyzyjne instrukcje co do trybu likwidacji bandytów. [...]

Pozostałe 828 osób sprawdzimy w ciągu pięciu dni - wszystkich wykrytych pośród nich bandytów zlikwidujemy w ten sam sposób. Meldunek o liczbie wykrytych w tej grupie bandytów zostanie Wam wysłany.

Proszę o dalsze instrukcje. Abakumow ${ }^{54}$.

52 List gen. Siergieja Szatiłowa, uprzednio pełnomocnika ZSRS przy PKWN, do premiera Tymczasowego Rządu Jedności Narodowej Edwarda Osóbki-Morawskiego z 18 lipca 1945 r. w sprawie wyjaśnienia tego mordu, w: Miotła Stalina..., s. 91-93.

53 Wstep, w: Miotla Stalina..., s. XV.

54 Szyfrogram nr 25212 W. Abakumowa, szefa GUKR SMIERSZ do narkoma Ł. Berii z 21 lipca 1945 r., w: N. Pietrow, Psy Stalina..., s. 224-225. 
To jest jedynie zamysł zbrodni, a nie raport końcowy $z$ jej wykonania, do którego zazwyczaj dołączano listę zamordowanych i czasami wskazywano miejsce egzekucji i pochówku. Nic nie wiemy o losach owych 828 „pod śledztwem”. Skoro się nie odnaleźli, to zapewne też podzielili los owych 592 „bandytów”. Jeśli dodamy do tego dość liczne jeszcze aresztowania po zakończeniu właściwego przeczesywania lasów, to liczba Ofiar jeszcze się zwiększy ${ }^{55}$. Ta teoria powstała w IPN w Białymstoku. Warto poznać jej podstawy teoretyczne i faktograficzne oraz autora.

Za niefortunną uważam także konkluzję, iż jakoby:

Była to największa masowa zbrodnia popełniona na cywilach w Europie pomiędzy zakończeniem drugiej wojny światowej a wybuchem wojen bałkańskich w latach dziewięćdziesiatych. Chociaż w czasie wojny i tuż po niej Sowieci przeprowadzili setki i tysiące operacji przeciwpartyzanckich, w które czasami zaangażowane były jednostki $\mathrm{ACz}$, to jednak najczęściej towarzyszyły im silne oddziały wojsk NKWD. Tymczasem w Augustowskiem partyzantów ścigali i aresztowali czerwonoarmiści, działajacy pod nadzorem oficerów Smierszu i we współpracy $z \mathrm{UB}^{56}$.

Takie stwierdzenie jest uprawnione po dokładnym zapoznaniu się $z$ dokumentacja wspomnianych 2609 obław, w tym 13 dużych na Kresach Wschodnich za rok (zapewne caly) 1945 i rok wcześniejszy ${ }^{57}$. I opatrzenie ich szczególna nazwa, np. (Wielkie) Obławy Kresowe 1944-1945.

Przeczy uznaniu Obławy Augustowskiej za największą powojenna zbrodnię też inna konkluzja:

Trzeba podkreślić, że umieszczenie obławy augustowskiej [nazwa własna, pisałbym dużymi literami - przyp. K.J.] w kontekście innych ówczesnych represji pozwala dostrzec jej unikalność. Choć brutalne komunistyczne pacyfikacje były powszechne, to jednak tylko obława augustowska przyniosła tak gigantyczną liczbę ofiar [też pisałbym dużą litera z szacunku dla pomordowanych] ${ }^{58}$.

Ale $z$ pewnościa trzeba to wszystko dokładnie zbadać i policzyć Ofiary. W moim przekonaniu zapewne największą okaże się Obława Nowogródzka. Być może bardziej trafną nazwa byłaby Obława Suwalsko-Augustowska zamiast tylko Obława Augustowska. Trudno powiedzieć, bo to też może poważnie skomplikować i tak mocno skomplikowany dyskurs w tej sprawie.

\footnotetext{
55 K. Jasiewicz, Obława Augustowska - stan badań..., passim.

Wstep, w: Miotła Stalina..., s. XV-XVI.

G. Motyka, Na białych Polaków obława..., s. 163.

58 Wstep, w: Miotła Stalina..., s. XV.
} 
Recenzowana praca zasługuję $z$ pewnością na wyróżnienie $z$ powodu sumienności badań i wyważonego komentarza. Jest jednak trochę stronnicza i powtarza, delikatnie mówiąc, tezy białostockich badaczy z IPN i ich guru - Alicji Maciejowskiej. Świadomie omijam ten watek ograniczając się do tej zdawkowej konkluzji, bo jego rozwijanie niczemu dobremu by nie służyło.

Krzysztof Jasiewicz

Warszawa

ORCID: 0000-0002-0330-2739 